\title{
Russell Shank Chosen Vice-President
}

Russell Shank, director of libraries at The Smithsonian Institution, Washington, D.C., was elected to the office of Vice-President/President-Elect of the Association of College and Research Libraries in the recent elections. With less than a third of the membership casting ballots, Shank polled 1,891 votes to E. J. Josey's 1,454 . Shank has served on the ACRL Board of Directors and is a past president of ALA's Information Science and Automation Division. $\mathrm{He}$ is currently chairman of the Advisory Committee to the Library Technology Program. Shank holds a B.S. in Electrical Engineering and a B.A. in Librarianship, both from the University of Washington; an M.B.A. from the University of Wisconsin; and a D.L.S. from Columbia University. He will serve as Vice-President through the end of the Annual Conference in 1972 when he will become the thirty-fourth president of the association.

Other results follow. (Elected officers are shown in italics.)

Vice-President/President-Elect: E. J. Josey, Chief, Bureau of Academic and Research Libraries, New York State Education Department, Albany, New York (1,454); Russell Shank, Director of Libraries, The Smithsonian Institution, Washington, D.C. $(1,891)$.

\section{COLLEGE LIBRARIES SECTION}

Vice-Chairman/Chairman-Elect: John $R$. Beard, Head Librarian and Professor, Montclair State College, Upper Montclair, New Jersey (566); R. Dean Galloway, College Librarian, Stanislaus State College, Turlock, California (379). Secretary: Sarah Katharine Thomson, College Librarian, Bergen Community College, Paramus, New Jersey (534); Richard J. Vorwerk, Director of University Libraries, Govemors State University, Park Forest, Illinois (391).

\section{JUNIOR COLLEGE LIBRARIES SECTION}

Vice-Chairman/Chairman-Elect: Janiece B. Fusaro, Periodicals, Pamphlets and Government Documents Librarian, Anoka-Ramsey State Junior College, Coon Rapids, Minnesota (190); William J. Hoffman, Director of Educational Media, Johnson County Community College, Shawnee Mission, Kansas (196). Secretary: Ambrose Easterly, Director of Library Services, Harper College, Palatine, Illinois (197); Virginia S. Hagebush, Assistant Dean of Instructional Resources, Meramec Community College, St. Louis, Missouri (179).

\section{RARE BOOKS SECTION}

Vice-Chairman/Chairman-Elect: Howard L. Applegate, Director, George Arents Research Library, Syracuse University, Syracuse, New York (247); John L. Sharpe, III, Curator of Rare Books, Duke University, Durham, North Carolina (219). Secretary: Harriet C. Jameson, Head, Department of Rare Books and Special Collections, University of Michigan, Ann Arbor, Michigan (264); Matthias P. Lowman, II, Assistant to the Director, The Newberry Library, Chicago, Illinois (202). Members-at-Large: (3 years) Frank S. Hanlin, Bibliographer, University of Iowa, Iowa City, Iowa (161); William J. Matheson, Chief, Rare Books and Special Collections, Washington University, St. Louis, Missouri (288); (2 years) Ann Bowden, Associate Editor, Papers of the Bibliographical Society of America, University of Texas, Austin, Texas (325); Chad J. Flake, Curator, Special Collections, Brigham Young University, Provo, Utah (134); (1 year) Robert O. Dougan, $L i-$ brarian, Henry E. Huntington Library and Art Gallery, San Marino, California (288); Mary L. Elder, Rare Books Librarian, St. Louis Public Library, St. Louis, Missouri (179).

\section{SUBJECT SPECIALISTS SECTION}

Vice-Chairman/Chairman-Elect: Alice $D$. Ball, Executive Director, U.S. Book Exchange, Washington, D.C. (449); Janet C. Price, Supervisor of Field Services, Bureau of Library Extension, Boston, Massachusetts (378).

\section{Agriculture and Biological Sciences} SUBSECTION

Vice-Chairman/Chairman-Elect: Elsie Bergland, Biomedical Sciences Librarian, Colorado State University Library, Fort Collins, Colorado (121); Eugenia Maddox, Head Librarian, Missouri Botanical Garden Library, St. Louis, Missouri (83). Secretary: Carolyn V. Kelleher, Research Librarian, Donaldson Company, Inc., Minneapolis, Minnesota (85); Elizabeth A. Windsor, Head, Reference Department, Iowa State University, Ames, Iowa (110).

\section{Art Subsection}

Vice-Chairman/Chairman-Elect: Judith A. Hoffberg, Bibliographer, University of California, San Diego, California (115); Jacqueline D. Sisson, Head, Fine Arts Library and Assistant Professor, Ohio State University Library, Columbus, Ohio (119). Secretary: G. Joan Burns, Principal Art Librarian, Newark Public Library, Newark, New Jersey (98); Nancy $R$. 
McAdams, Architecture and Planning Librarian, University of Texas, Austin, Texas (128).

Asian and North African Subsection

Vice-Chairman/Chairman-Elect: Adrian Jones, Director of Libraries, Roosevelt University, Chicago, Illinois (50); Theodore $F$. Welch, Assistant University Librarian, Public Services, Northwestern University Library, Evanston, Illinois (71). Member-at-Large: Charles R. Bryant, Curator, Southeast Asia Collection, Yale University Library, New Haven, Connecticut (78); Lee S. Dutton, Southeast Asia Librarian, Northern Illinois University, DeKalb, Illinois (41)

Education and Behavioral Sciences SUBSECTION

Vice-Chairman/Chairman-Elect: Robert $N$. Broadus, Professor of Library Science, Northern Illinois University, DeKalb, Illinois (207); Emil Greenberg, Professor and Chairman of Library Technology, Manhattan Community College, New York, New York (124). Secretary; Lois I. Renter, Head Librarian, American College Testing Program, Iowa City, Iowa (103); Rose Marie Service, Social Science Librarian, University of Oregon, Eugene, Oregon (216).

Law and Political Science Subsection

Vice-Chairman/Chairman-Elect: Judy
Fair, Chief, Government Documents Department and Microtext and Newspaper Room, Stanford University, Stanford, California (182); Roy H. Fry, Reference and Documents Librarian, Loyola University, Chicago, Illinois (90). Member-at-Large: Jennie B. Cross, Documents Librarian, Kresge Library, Oakland University, Rochester, Michigan (115); Michael O. Shannon, Assistant Professor and Reference Librarian, Herbert Lehman College, Bronx, New York (152).

Slavic and East European Subsection

Vice-Chairman/Chairman-Elect: Wasyl Veryha, General Cataloger, University of Toronto, Toronto, Ontario, Canada (59); Lubomyr $R$. Wynar, Professor, School of Library Science, Kent State University, Kent, Ohio (75). Member-at-Large: D. Whitney Coe, Head, Descriptive Cataloging Section, Princeton University, Princeton, New Jersey (53); Anna K. Stuliglowa, Slavic Studies Librarian, Cornell University Library, Ithaca, New York (78).

\section{UNIVERSITY LIBRARIES SECTION}

Vice-Chairman/Chairman-Elect: Lemoyne W. Anderson, Director of Libraries, Colorado State University, Fort Collins, Colorado (1,045); Isaac T. Littleton, Director, D. H. Hill Library, North Carolina State University, Raleigh, North H. Carolina (544).

\section{WHAT'S NEW IN THE WORLD OF LIBRARIANSHIP? PROLLAP}

PROLLAP is a specialized approval plan. But there is no existing approval plan quite like it. PROLLAP is intended to meet the information needs of librarians, information scientists, and library students. It is a plan designed to acquire the literature of librarianship. PROLLAP will supply not only the publications of the well known publishers, but also ephemeral publications which are difficult to secure. A program can be designed for all types of libraries - both large and small. One can be designed for yours.

The benefits of PROLLAP are:

1 reduce the costs of selecting and ordering publications

2 support continuing education programs of library staff

3 support library education programs

4 broaden coverage of important ephemeral materials

For further information about the Professional Library Literature Acquisition Program, write to:

\section{E.B.S. INC. BOOK SERVICE (DEPT. P) 290 Broadway Lynbrook, New York 11563}

Please send comprehensive description of PROLLAP plan INSTITUTION DEPT. 